\title{
Comparison of olive pomace and biowaste composts in a vegetable cropping system
}

\author{
Luigi Morra, Gaetano Pizzolongo, Salvatore Baiano, Alfonso Pentangelo \\ Consiglio per la Ricerca e la Sperimentazione in Agricoltura, Unità di Ricerca per le Colture \\ Alternative al Tabacco, Scafati (SA), Italy
}

\begin{abstract}
The main objective of this paper was to study the growth and the yield responses of different vegetable crops to pomace compost and biowaste (source-separated municipal organic fraction) compost and to the increase in their rates. A secondary aim was to assess the efficiency of nitrogen $(\mathrm{N})$ supplied to the crops by the compost rate integrated or not with $\mathrm{N}$ fertilisers. Finally, the ability of the two composts to improve the soil organic carbon content was also compared. The research was carried out from July 2009 to June 2011. A comparison was made of treatments resulting from the factorial combination of two composts, two rates of application, and two levels of nitrogen fertiliser. A non-fertilised control was also analysed and a standard mineral fertilisation completed the group of treatments. Cauliflower and potato were harvested after the first compost distribution, and onion and lettuce after the second. Our results indicated that the higher the quantity of olive pomace compost applied the greater the slow release of $\mathrm{NO}_{3}-\mathrm{N}$ for crop needs. This has to be related to the high carbon:nitrogen ratio of the olive pomace compost.The halved rate of $\mathrm{N}$ fertiliser added to compost was sufficient to overcome the competition between soil microorganisms and roots for nitrogen, only on the second crop in the annual sequence. The biowaste compost without $\mathrm{N}$ fertiliser integration also reduced crop yields, but this was to a lesser degree than that achieved with olive pomace compost and was independent of the rate applied.
\end{abstract}

The halved rate of $\mathrm{N}$ fertiliser supplied was able to overcome the problems of nitrogen availability. As a consequence, the nitrogen utilisation efficiency showed a higher recovery of nitrogen from biowaste compost

Correspondence: Luigi Morra, Unità di Ricerca per le Colture Alternative al Tabacco, via Pasquale Vitiello 106, 84018 Scafati (SA), Italy.

E-mail: luigi.morra@entecra.it

Key words: yields, nitrogen use efficiency, nitrogen surplus, organic carbon balance.

Funding: this research was funded by the Assessorato all'Agricoltura of the Campania Region, Italy, with the Project Compostaggio di sanse olearie e valorizzazione agronomica e merceologica del compost.

Received for publication: 24 February 2013.

Revision received: 28 July 2013.

Accepted for publication: 29 July 2013.

(C) Copyright L. Morra et al., 2013

Licensee PAGEPress, Italy

Italian Journal of Agronomy 2013; 8:e25

doi:10.4081/ija.2013.e25

This article is distributed under the terms of the Creative Commons Attribution Noncommercial License (by-nc 3.0) which permits any noncommercial use, distribution, and reproduction in any medium, provided the original author(s) and source are credited. than from olive pomace compost, as well as from the $10 \mathrm{t} \mathrm{ha}^{-1}$ dose (rate 10) of dry matter than from the $20 \mathrm{tha}^{-1}$ dose. On the other hand, the soil organic carbon content increased significantly only when the composts were added at doses of $20 \mathrm{tha}^{-1}$.

\section{Introduction}

Composting of solid, semi-solid and liquid olive mill residues has been the subject of extensive study as a potential bioremediation treatment of these wastes (Alfano et al., 2009a). Composting avoids the negative effects observed when these wastes are directly applied to soil. Besides, the high purity of olive mill wastes could ensure the quality and competitiveness of composts made from biological transformation of these residues (Roig et al., 2006). Many studies have been carried out over the last 15 years in order to further define the chemical, physical and microbiological characteristics of the composting process, depending on whether two or three phase olive mill wastes were composted (Canet et al., 2008; Alburquerque et al., 2006a, 2006b; Baeta-Hall et al., 2005; Vallini et al., 2001). At the same time, much effort has been made to find the most suitable composting technologies (Altieri and Esposito, 2012; Morra et al., 2012; Alfano et al., 2008). Unlike the extensive literature available on composting technologies, composting processes, and on the chemical and microbiological characteristics of the mature olive pomace compost, studies on its agronomic effects are not exhaustive (Garcia-Ruiz et al., 2012; Altieri and Esposito, 2010). In general, some information is available from shortterm trials. Regarding the effects on the growth and yields of vegetables, cereals or leguminous crops, Alfano et al. (2009b) detected an increase in photosynthetic rate, plant dry weight (d.w.), number of fruits of tomato when amended by 3 or $10 \mathrm{t} \mathrm{ha}^{-1}$ of pomace compost on a fresh weight basis (corresponding to 2.1 and $6.4 \mathrm{t} \mathrm{ha}^{-1}$ d.w.) integrated by $270 \mathrm{~kg} \mathrm{ha}^{-1}$ of mineral nitrogen (N) fertiliser. In the absence of $\mathrm{N}$ fertilisation, the rates of compost tested significantly lowered these parameters. Altieri and Esposito (2010), in field trials using tomato and lettuce, concluded that combination of pomace compost and halfdose of an inorganic nitrogen-phosphorus-potassium (NPK) fertiliser improved plant production compared with only compost amended and unfertilised soil control. Hachicha et al. (2006) and Rigane and Medhioub (2011) recorded the same potato yields in soils amended with manure or with $30 \mathrm{t} \mathrm{ha}^{-1}$ of pomace compost. Montemurro et al. (2004) and Diacono et al. (2009) found that rye-grass and emmer fresh matter production was negatively influenced by the high carbon:nitrogen $(\mathrm{C}: \mathrm{N})$ ratio $(>30)$ of pomace compost.

Regarding the effects of pomace compost in improving fertility and structural stability of soil, Pardini et al. (2008) carried out a pot experiment in 2003-2006 with two Spanish soils that were very poor in organic matter. They found that the addition of pomace compost increased the aggregate stability under raindrop, water retention and soil respiration. In contrast, many other Authors have reported an increase in soil organic matter (SOM) after a single amendment with 
compost, but the period of time studied was too short to be able to identify any stable change in SOM content (Altieri and Esposito, 2010; Hachicha et al., 2006; Montemurro et al., 2004). Compost amendment has to be studied also for its influence on $\mathrm{N}$ utilisation efficiency. The efficiency of the $\mathrm{N}$ applied in satisfying the $\mathrm{N}$ demand of the crops depends on the type of fertiliser, the timing of application, seasonal trends, soil type, crop sequence and the supply of residual and mineralised N (Lopez-Bellido et al., 2005).

The experiment discussed in this article aimed to: i) study the growth and the yield responses of different vegetable crops to the pomace compost and municipal organic fraction waste (biowaste) compost and the increase in their rates; ii) to assess the efficiency of nitrogen supplied to the crops by the compost rates alone or integrated with mineral $\mathrm{N}$ fertilisers; and, finally, iii) compare the ability of the pomace and biowaste composts to improve the soil organic carbon balance.

\section{Materials and methods}

\section{Study site and layout}

The research was carried out in the period from July 2009 to June 2011 at the experimental farm of the Research Unit for Alternative Crops to Tobacco at Scafati, Salerno, southern Italy (Unità di Ricerca per le Colture Alternative al Tabacco, CRA). The soil is a vitric andosol calcaric, sandy-loam textured, with 458,502 and $40 \mathrm{~g} \mathrm{~kg}^{-1}$ of sand, silt and clay, respectively. Main chemical characteristics at the start of the trial were: $\mathrm{pH}_{(\mathrm{H} 20)} 8.4$, electrical conductivity $\left(25^{\circ} \mathrm{C}, 1: 2\right) 0.34 \mathrm{dS} \mathrm{cm}-1$, soil organic carbon (SOC) $12.7 \mathrm{~g} \mathrm{~kg}^{-1}$, total $\mathrm{N} 1.28 \mathrm{~g} \mathrm{~kg}^{-1}$, available $\mathrm{P}_{2} \mathrm{O}_{5}$ $115 \mathrm{mg} \mathrm{kg}^{-1}$, exchangeable $\mathrm{K}_{2} \mathrm{O} 758 \mathrm{mg} \mathrm{kg}^{-1}$, exchangeable Ca $3120 \mathrm{mg}$ $\mathrm{kg}^{-1}$. The compared treatments resulted from the factorial combination of the pomace and biowaste composts (CompS and CompF, respectively) distributed in two rates of application (10 and 20 ton ha $\mathrm{ha}^{-1}$ on a dry matter basis) and integrated with two levels of nitrogen fertiliser ( 0 or half the optimal dose for NPK treatment); a non-fertilised control (NFC) and a standard mineral fertilisation (NPK) completed the group of treatments arranged in a completely randomised block design with three replications. Each experimental unit measured $5 \times 3.2 \mathrm{~m}$, equal to an area of $16 \mathrm{~m}^{2}$. The tested composts were produced with olive pomace from three phase olive mills and municipal source-separated organic fraction. CompS was made mixing olive pomace $(63 \% \mathrm{w} / \mathrm{w})$, cow manure (30\%) and wheat straw (7\%) in 2009, while in 2010, olive pomace $(71 \% \mathrm{w} / \mathrm{w})$, waste pruning $(16 \%)$, and fresh residues of postharvest processing of fennel (13\%) were mixed. The main chemical characteristics after a composting process of 120 days in 2009 and 160 days in 2010 were, respectively: total organic carbon (TOC) 40\% and $38 \%$ on dry matter, humic acids $10.2 \%$ and $9.7 \%$, total $\mathrm{N} 1.3 \%$ and $1.4 \%$, organic N 95\% and $97 \%$ of total N, C:N ratios 32 and 28, germination indexes $85 \%$ and $75 \%$. CompF was produced at the GESENU S.p.A. plant in Perugia, central Italy in 2009 and at the PROGEVA s.r.l. plant of Laterza, Taranto, Italy, in 2010. The main chemical characteristics of the GESENU and PROGEVA composts were: TOC 28 and 28.8, respectively, humic acids 14.2 and 9.5 , total N 2.1\% and 1.7\%, organic N 95\& and $93 \%$ of total N, C:N 13 and 16.

\section{Vegetable cropping system}

The set of treatments described above was tested in an open field vegetable cropping system. A cauliflower-potato sequence was carried out in the first year and an onion-lettuce sequence in the second. Table 1 shows the main information about the cropping cycles. Crop yields were assessed harvesting on a sub-area of $6.4 \mathrm{~m}^{2}$ (cauliflower), $4 \mathrm{~m}^{2}$ (potato), $2.4 \mathrm{~m}^{2}$ (onion) and $2.1 \mathrm{~m}^{2}$ (lettuce). Crop residues of cauliflower and potato were not buried in soil while onion (bulbs and leaves) and lettuce were completely removed at harvesting. Therefore, the study of soil organic carbon balance did not take into account the OC supplied by the aboveground parts of crops.

Table 2 shows the amounts of nitrogen distributed by composts and fertilisers on each crop in the two years. Crop needs of nitrogen were determined according to the guidelines of the Regional Agricultural Committee (Assessorato Agricoltura Regione Campania, 2003). Due to the high inherent soil fertility, neither phosphorus nor potassium supplies were needed.

Table 2 also shows the maximum $\mathrm{N}$ amounts permitted by the Action Programme on the study site for areas at risk of nitrate pollution from agricultural sources (Assessorato Agricoltura Regione Campania, 2008).

\section{Nitrogen utilisation efficiency and budget}

Crop $\mathrm{N}$ uptake of aboveground plant parts was determined at harvest in all treatments. Fresh and dry aboveground crop biomass of cauliflower was determined by sampling three fresh cauliflower plants per plot, weighing separately the heads and the stem plus leaves, choosing from these two epigeic parts as many sub-samples as per replication. These sub-samples were weighed and oven dried up to constant weight at $65^{\circ} \mathrm{C}$. The same procedure was repeated for potato, onion and lettuce; the only difference was that the initial sampling was carried out collecting all the plants + tubers/bulbs of the plot. Sub-samples of the dry material were analysed for total $\mathrm{N}$ concentration determining the organic $\mathrm{N}$ according to the method of Kjeldhal and the mineral $\mathrm{N}\left(\mathrm{NH}_{4}{ }^{+}\right.$ $-\mathrm{N}$ and $\mathrm{NO}_{3}-\mathrm{N}$ ) by stirring the sample for approximately $30 \mathrm{~min}$ in a $5 \%$

Table 1. Main field operations during the 2-year trial.

\begin{tabular}{|c|c|c|c|c|c|c|c|c|}
\hline Crop & Cultivar & $\begin{array}{l}\text { Planting } \\
\text { date }\end{array}$ & $\begin{array}{c}\text { Plant } \\
\text { density }\end{array}$ & $\begin{array}{l}\text { Spreading } \\
\text { and/or tillage } \\
\text { date }^{*}\end{array}$ & $\begin{array}{l}\mathbf{N} \text { fertilisers } \\
\text { spreading }\end{array}$ & $\begin{array}{l}\text { Irrigation } \\
\text { system }\end{array}$ & $\begin{array}{l}\text { Weed } \\
\text { control }^{\circ}\end{array}$ & $\begin{array}{l}\text { Harvest } \\
\text { date }^{\#}\end{array}$ \\
\hline Cauliflower & Megha & $09-23-07$ & 2.5 plants $\mathrm{m}^{-2}$ & 09-23-07 & $09-23-07$ and $09-18-08^{\S}$ & Drip irrigation & $4 x$ & $09-09-10$ \\
\hline Potato & Adora & $10-01-03$ & 6.2 tubers $\mathrm{m}^{-2}$ & $10-20-02$ & $10-25-02$ and $10-01-04^{\S}$ & Drip irrigation & $2 x$ & $10-24-06$ \\
\hline Onion & Bianca di Pompei & $10-15-11$ & 25 plants $\mathrm{m}^{-2}$ & $10-10-09$ & $\begin{array}{c}10-11-11,11-05-02, \\
11-10-03 \text { and } 11-15-04^{\wedge}\end{array}$ & Drip irrigation & Propaquizafop & $11-03-05$ \\
\hline Lettuce & Ballerina & $11-24-05$ & 9.6 plants $\mathrm{m}^{-2}$ & $11-20-05$ & $11-20-05^{\$}$ & Drip irrigation & $2 x$ & $11-08-07$ \\
\hline
\end{tabular}

*Composts were spread once a year and tilled in the same day before cauliflower and onion cycles. Primary and secondary tillage was with rotovator at a max $0.25 \mathrm{~m}$ depth; ${ }^{\circ} \mathrm{denotes}$ number of times the crop was cultivated by rotovator or manual hoeing. The erbicide was applied in pre-emergence; ${ }^{*}$ indicates the start of harvest cycle; $\$ 50 \%$ in pre-transplant with ammonium sulphate and $50 \%$ in top dressing with ammonium nitrate;

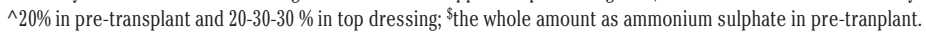


solution of acetic acid, followed by filtering and measurement by flow colorimetry (AutoAnalyzer III, Braun Luebbe) according to Berthelot's reaction for ammonium and the Griess-Ilosvay's reaction for nitrate. Aboveground crop $\mathrm{N}$ was calculated as the product of dry biomass and total $\mathrm{N}$ concentration. Due to a management mistake, the samples of dried lettuce were weighed for the measure of dry matter but they were destroyed before the $\mathrm{N}$ content could be measured. However, in order to assess the $\mathrm{N}$ balance of the whole crop sequence, the $\mathrm{N}$ uptake of lettuce was calculated on the basis of an $\mathrm{N}$ leaf concentration of $36 \mathrm{~g} \mathrm{~kg}^{-1}$ d.w. averaged by data reported in Marsic and Osvald (2002), Tei et al. (2003) and Gent (2002).

The $\mathrm{N}$ budget was constructed as a simple running balance sheet where the annual crop $\mathrm{N}$ outputs were subtracted from the annual $\mathrm{N}$ inputs. Outputs included all whole aboveground biomasses (Reider et al., 2000).

Some $\mathrm{N}$ efficiency parameters were determined. The apparent $\mathrm{N}$ recovery (REC) was estimated on the basis of the $\mathrm{N}$ uptake of the unfertilised control:

$$
\mathrm{REC}=\left(\mathrm{U}_{\mathrm{F}}-\mathrm{U}_{0}\right) / \mathrm{N}_{\mathrm{F}}
$$

where:

$N_{F}$ is fertiliser- $N$ rate $\left(\mathrm{kg} \mathrm{ha}^{-1}\right), \mathrm{U}_{\mathrm{F}}$ is $\mathrm{N}$ uptake $\left(\mathrm{kg} \mathrm{ha}^{-1}\right)$ when $\mathrm{N}_{\mathrm{F}}$ is given, $\mathrm{U}_{0}$ is $\mathrm{N}$ uptake $\left(\mathrm{kg} \mathrm{ha}^{-1}\right)$ in non-fertilised plots.

The utilisation efficiency of absorbed $\mathrm{N}\left(\mathrm{N}_{\mathrm{a}} \mathrm{UE}\right)$ was calculated as the total crop dry matter accumulated or the fresh matter in marketable yield per kg of absorbed N (Benincasa et al., 2011).

\section{Soil organic matter data}

TOC at a depth of $0-30 \mathrm{~cm}$ was detected according to the method of Walkley Black. Soil samples were collected in each experimental unit before the distribution of fertilisers and soil improvers on $22^{\text {nd }}$ July 2009. Each sample contained three soil cores. Soil was then sampled at the end of the first crop sequence (cauliflower-potato) on $14^{\text {th }}$ July 2010. The final sampling occurred after the end of the second crop sequence on $13^{\text {th }}$ July 2011.

\section{Statistical analyses}

All data recorded were elaborated by analysis of variance applying a model where each experimental treatment was defined as the factorial combination of the three experimental factors plus the controls. Means separation was performed either applying the Tukey HSD test $(\mathrm{P}=0.05)$ for soil $\mathrm{N}$ surplus or applying a set of nine single degree of freedom orthogonal contrasts for yields, $\mathrm{N}$ efficiency indices and TOC data. The set of contrasts was based on the objectives stated earlier to compare different logical combinations of fertilisation strategies: i) composts versus controls: all the amended compost treatments compared to the controls, non-fertilised and mineral fertilised; ii) NPK versus NFC: the control mineral fertilised compared with the non-fertilised control; iii) CompF versus CompS: all treatments amended with CompF compared to those amended with CompS; iv) CompF10-20 versus CompF10-20 +N: compares the average effect of both the rates of CompF alone or integrated with $\mathrm{N}$ fertiliser; v) CompF10 versus CompF20: comparison between the two rates of $\mathrm{CompF}$ not integrated by $\mathrm{N}$; vi) $\mathrm{CompF} 10+\mathrm{N}$ versus CompF20+N: comparison between the two rates of CompF integrated by $\mathrm{N}$; vii) CompS10-20 versus CompS10-20 +N: compares the average effect of both the rates of CompS alone or integrated with $\mathrm{N}$ fertiliser; viii) CompS10 versus CompS20: comparison between the two rates of CompS not integrated by $\mathrm{N}$; ix) CompS10+N versus $\mathrm{CompS20+N}$ : comparison between the two rates of CompS integrated by $\mathrm{N}$.

\section{Results}

\section{Dry and fresh matter yields}

After the first soil amendment by compost in July 2009, the first crop was cauliflower; dry and fresh matter yields are shown in Table 3 . Total biomass dry matter ranged from $4.1 \mathrm{t} \mathrm{ha}^{-1}$ of CompS20 to 5.8 of NPK, while marketable yields ranged from $10.7 \mathrm{t} \mathrm{ha}^{-1}$ of CompS20 to 19.8 of NPK. On average, dry matter in heads represented $24 \%$ of total dry matter of crop. The performed orthogonal contrasts indicated that total biomass dry matter as well as marketable yields and mean fresh weight of heads of controls (NPK and NFC treatments) were on average higher than those from the compost-amended treatments. This result, particularly for the non-fertilised control, was made possible by the initial high soil fertility. The addition of CompF determined, on average, a partition of dry matter in head, marketable yields and head fresh mean weight higher than CompS treatments. Looking at the effect of the applied rates of compost, it can be observed that either CompF10 versus

Table 2. Amounts of nitrogen supplied by composts and/or nitrogen $(\mathrm{N})$ fertilisers on each crop in the two years. In brackets are the yearly maximum $\mathrm{N}$ amounts admitted for the vegetables cropped according to the Action Programme in areas vulnerable to nitrates of Campania Region.

\begin{tabular}{|c|c|c|c|c|c|c|c|c|c|}
\hline & $\begin{array}{l}\text { Compost } \\
\text { rate } \\
\left(\mathrm{t} \mathrm{ha} \mathbf{a}^{-1}\right)\end{array}$ & $\begin{array}{l}\mathrm{N} \text { tot } \\
\text { by compost } \\
\left(\mathrm{kg} \mathrm{ha} \mathrm{ha}^{-1}\right)\end{array}$ & $\begin{array}{l}2009 / 2010 \\
\text { Cauliflower } \\
\text { Nmin rate } \\
\left(\mathrm{kg} \mathrm{ha}^{-1}\right)\end{array}$ & $\begin{array}{c}\text { Potato } \mathrm{Nmin} \\
\text { rate } \\
\left(\mathrm{kg} \mathrm{ha}^{-1}\right)\end{array}$ & $\begin{array}{l}\text { Total }{ }^{\text {st }} \\
N \text { year } \\
\left(\mathrm{kg} \mathrm{ha}^{-1}\right)\end{array}$ & $\begin{array}{l}\mathrm{N} \text { tot by } \\
\text { compost } \\
\left(\mathrm{kg} \mathrm{ha}^{-1}\right)\end{array}$ & $\begin{array}{c}2010 / 2011 \\
\text { Onion Nmin } \\
\text { rate } \\
\left(\mathrm{kg} \mathrm{ha}^{-1}\right)\end{array}$ & $\begin{array}{l}\text { Lettuce } \\
\text { Nmin rate } \\
\left(\mathrm{kg} \mathrm{ha}^{-1}\right)\end{array}$ & $\begin{array}{c}\text { Total } 2^{\text {nd }} \\
\begin{array}{c}N \\
\left(\mathrm{~kg} \mathrm{ha}^{-1}\right)\end{array}\end{array}$ \\
\hline $\begin{array}{l}\text { Mineral N } \\
\text { fertilisation }\end{array}$ & & & 110 & 160 & $270(350)$ & & 120 & 80 & 200 (238) \\
\hline $\begin{array}{l}\text { Olive pomace } \\
\text { compost }\end{array}$ & $\begin{array}{l}10 \\
20\end{array}$ & $\begin{array}{l}126 \\
252\end{array}$ & $\begin{array}{c}0 \\
55 \\
0 \\
55\end{array}$ & $\begin{array}{c}0 \\
80 \\
0 \\
80\end{array}$ & $\begin{array}{l}126 \\
261 \\
252 \\
387\end{array}$ & $\begin{array}{l}137 \\
274\end{array}$ & $\begin{array}{c}0 \\
60 \\
0 \\
60\end{array}$ & $\begin{array}{c}0 \\
40 \\
0 \\
40\end{array}$ & $\begin{array}{l}137 \\
237 \\
274 \\
374\end{array}$ \\
\hline $\begin{array}{l}\text { Municipal organic } \\
\text { fraction compost }\end{array}$ & $\begin{array}{ll}\text { ic } & 10 \\
\text { t } & 20\end{array}$ & $\begin{array}{l}210 \\
420\end{array}$ & $\begin{array}{c}0 \\
55 \\
0 \\
55\end{array}$ & $\begin{array}{c}0 \\
80 \\
0 \\
80\end{array}$ & $\begin{array}{l}210 \\
345 \\
420 \\
555\end{array}$ & $\begin{array}{l}200 \\
400\end{array}$ & $\begin{array}{c}0 \\
60 \\
0 \\
60\end{array}$ & $\begin{array}{c}0 \\
40 \\
0 \\
40\end{array}$ & $\begin{array}{l}200 \\
300 \\
400 \\
500\end{array}$ \\
\hline
\end{tabular}

$\mathrm{N}$, nitrogen. 
CompF20, or CompS10 versus CompS20 indicated that the higher marketable yields and dry and fresh weight of heads were obtained with the $10 \mathrm{t} \mathrm{ha}^{-1}$ dose when compared with the $20 \mathrm{t} \mathrm{ha}^{-1}$ dose. Table 4 shows the potato production either as dry matter of stems + leaves and tubers or as total fresh weight of tubers subdivided into two main size classes. The dry matter accumulated in tubers was, on average, $87 \%$ of the total biomass. The total biomass dry matter ranged from $6 \mathrm{t} \mathrm{ha}^{-1}$ of CompS20 to 9.2 of CompS10+N while the marketable yields ranged from $25.8 \mathrm{t} \mathrm{ha}^{-1}$ of CompS20 to 41.2 of CompS10+N, clearly highlighting the crucial role of the addition of mineral nitrogen to the lower rate of CompS. Means separation by orthogonal contrasts showed the following significant effects: i) the potato yields were lower in the NFC with respect to the NPK control; ii) the addition of 10 or $20 \mathrm{t} \mathrm{ha}^{-1}$ of both the composts determined higher yields when $80 \mathrm{~kg} \mathrm{ha}^{-1}$ of $\mathrm{N}$ fertiliser was used.

The second compost amendment took place in November 2010 (Table 1), and the onion crop was then carried out. Table 5 shows the onion production either as dry matter of leaves and bulbs or as marketable yield, mean bulb diameter and weight. The dry matter accumulated in bulbs was, on average, $83 \%$ of the total. Total biomass dry matter ranged from $1.1 \mathrm{t} \mathrm{ha}^{-1}$ of CompS20 to 3.1 of CompF20+N and marketable yields ranged from $7.5 \mathrm{t} \mathrm{ha}^{-1}$ of CompS20 to 30.7 of CompF20+N. The pattern of crop yield response to the treatments was substantially the same as that observed with potato. The onion yields were lower again in NFC with respect to NPK control. CompF showed an increase in average crop production when compared with CompS. The addition of the two composts applied at both the rates, if not inte- grated by mineral $\mathrm{N}$, reduced yields. In particular, CompS resulted in a big reduction in growth and productivity that was directly proportional to the amount of the rate supplied. The addition of $\mathrm{N}$ helped crop $\mathrm{N}$ uptake allowing an improvement in yields in CompF at 10 or $20 \mathrm{tha}^{-1}$ and in CompS10, while in CompS at $20 \mathrm{t} \mathrm{ha}^{-1}$ the yield was, however, as low as in NFC. Also lettuce response was similar to onion and potato (Table 6). Total biomass dry matter as well as marketable yields ranged, respectively, from 2.1 and $19.2 \mathrm{t} \mathrm{ha}^{-1}$ in NFC to 2.8 and $47.6 \mathrm{t}$ $\mathrm{ha}^{-1}$ in NPK. Orthogonal contrasts indicated that the marketable yields and the head mean weight of lettuce were negatively influenced by NFC in comparison to NPK, as well as by CompS in comparison to CompF. In addition, the use of CompF or CompS at both the rates caused a significant reduction in the marketable yields and head mean weight if mineral $\mathrm{N}$ fertiliser was not added.

\section{Nitrogen utilisation efficiency indexes}

Tables 7-9 present data on $\mathrm{N}$ uptake of aboveground crop, $\mathrm{N}$ removal with the marketable parts of plants, the $\mathrm{N}$ utilisation efficiency and $\mathrm{N}$ apparent recovery of the cauliflower, potato and onion crops. The data in Table 7 show the $\mathrm{N}$ utilisation efficiency indexes of cauliflower. The plants on compost-treated plots showed, on average, a significantly lower N uptake than NFC and NPK controls, as well as for N removal by heads and for $\mathrm{N}$ apparent recovery. $\mathrm{N}$ uptake and its apparent recovery were higher in CompF than CompS. Only NaUE on aboveground dry weight was higher in compost-treated plots. As seen from Table 7, this index is higher where $\mathrm{N}$ nutrition was poorer (compare the trend of $\mathrm{N}$ uptake). It also revealed a difference between the group of CompF

Table 3. Fresh marketable yields and total dry matter biomass of cauliflower cropped in summer 2009, immediately after the first soil compost amendment.

\begin{tabular}{|c|c|c|c|c|c|}
\hline Treatments & $\begin{array}{l}\text { Stem+leaves dry matter } \\
\qquad\left(\mathrm{tha}^{-1}\right)\end{array}$ & $\begin{array}{l}\text { Head dry matter } \\
\qquad\left(\mathrm{tha} \mathrm{h}^{-1}\right)\end{array}$ & $\begin{array}{l}\text { Total dry matter } \\
\qquad\left(\mathrm{t} \mathrm{ha} \mathrm{a}^{-1}\right)\end{array}$ & $\begin{array}{l}\text { Marketable Yield } \\
\qquad\left(\mathrm{t} \mathrm{ha}^{-1}\right)\end{array}$ & $\begin{array}{l}\text { Head mean weight } \\
\text { (g) }\end{array}$ \\
\hline CompF10 & 4.0 & 1.5 & 5.5 & 19.3 & 753 \\
\hline CompF20 & 3.8 & 1.1 & 4.9 & 14.5 & 653 \\
\hline CompF10+N & 4.2 & 1.3 & 5.5 & 18.0 & 784 \\
\hline CompF20+N & 4.2 & 1.3 & 5.5 & 15.7 & 788 \\
\hline CompS10 & 3.8 & 1.2 & 5.0 & 12.2 & 645 \\
\hline CompS20 & 3.3 & 0.8 & 4.1 & 10.7 & 557 \\
\hline CompS10+N & 4.4 & 1.3 & 5.7 & 15.7 & 724 \\
\hline CompS20+N & 4.5 & 1.0 & 5.5 & 13.3 & 693 \\
\hline NPK & 4.2 & 1.6 & 5.8 & 19.8 & 926 \\
\hline NFC & 4.1 & 1.6 & 5.7 & 15.2 & 760 \\
\hline \multicolumn{6}{|l|}{ Orthogonal contrasts } \\
\hline Compost $v s$ controls & ns & $-0.45^{* * *}$ & ns & $-2.6^{*}$ & $-143^{* * *}$ \\
\hline NPK us NFC & ns & ns & ns & $4.6^{*}$ & $166^{* *}$ \\
\hline CompF us CompS & ns & $0.2^{*}$ & ns & $3.8^{* *}$ & $90 * * *$ \\
\hline CompF10-20 us CompF10-20 +N & ns & ns & ns & ns & $-83^{* *}$ \\
\hline CompF10 us CompF20 & ns & $0.38^{*}$ & ns & $4.8^{*}$ & $100 * *$ \\
\hline CompF10+N us CompF20+N & ns & ns & ns & ns & ns \\
\hline CompS10-20 us CompS10-20 +N & ns & ns & ns & ns & $-107^{* *}$ \\
\hline CompS 10 us CompS 20 & ns & $0.37^{*}$ & ns & ns & ns \\
\hline CompS 10+N us CompS 20+N & ns & ns & ns & ns & ns \\
\hline
\end{tabular}

CompF, municipal source separated organic fraction compost; CompS, olive pomace compost; CompF and CompS followed by 10 and 20 are the rates of compost, $+\mathrm{N}$ indicates the addition of mineral $\mathrm{N}$ fertilizer; $\mathrm{NPK}$, nitrogen-phosphorus-potassium; NFC, non-fertilised control; ns, not significant difference. The positive or negative values on the left of asterisks indicate the difference between the first (+) or the second (-) mean of the two contrasted groups; * **, *** indicate the significant levels of the contrasts, respectively $\mathrm{P}=0.05 ; \mathrm{P}=0.01 ; \mathrm{P}<0.001$. 
Table 4. Fresh marketable yields and total dry matter biomass of potato cropped on winter-spring 2010 after the cauliflower cycle.

\begin{tabular}{|c|c|c|c|c|c|c|}
\hline Treatments & $\begin{array}{c}\text { Stem+leaves } \\
\text { dry matter } \\
\left(\mathrm{t} \mathrm{ha}^{-1}\right)\end{array}$ & 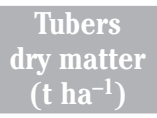 & $\begin{array}{c}\text { Total } \\
\text { dry matter } \\
(\mathrm{t} \mathrm{ha-1)}\end{array}$ & $\begin{array}{l}\text { Marketable yield } \\
\qquad\left(\mathrm{t} \mathrm{ha} \mathbf{a}^{-1}\right)\end{array}$ & 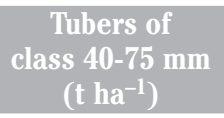 & 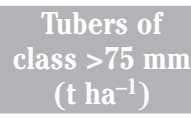 \\
\hline CompF10 & 0.96 & 5.8 & 6.8 & 28.5 & 24.3 & 1.8 \\
\hline CompF20 & 0.96 & 6.5 & 7.5 & 32.9 & 28.1 & 3.2 \\
\hline CompF10+N & 1.40 & 7.1 & 8.5 & 38.7 & 31.0 & 4.8 \\
\hline CompF $20+\mathrm{N}$ & 1.21 & 7.8 & 8.1 & 40.6 & 31.8 & 4.9 \\
\hline CompS10 & 0.83 & 5.3 & 6.1 & 26.0 & 23.3 & 0.0 \\
\hline CompS20 & 0.76 & 5.3 & 6.0 & 25.8 & 22.2 & 1.0 \\
\hline CompS10+N & 1.22 & 8.0 & 9.2 & 41.2 & 34.2 & 3.7 \\
\hline CompS20+N & 1.25 & 7.7 & 8.9 & 40.4 & 33.7 & 4.5 \\
\hline NPK & 1.30 & 6.8 & 8.1 & 39.1 & 33.4 & 2.5 \\
\hline NFC & 0.91 & 5.5 & 6.4 & 27.4 & 23.8 & 0.9 \\
\hline \multicolumn{7}{|l|}{ Orthogonal contrasts } \\
\hline Compost vs controls & ns & ns & ns & ns & ns & $1.2^{*}$ \\
\hline NPK us NFC & $0.38^{* *}$ & $1.7^{* *}$ & $1.7^{* *}$ & $11.6^{* * *}$ & $9.5^{* * *}$ & n.s. \\
\hline CompF us CompS & ns & ns & ns & ns & ns & $1.3^{* *}$ \\
\hline CompF10-20 us CompF10-20 +N & $-0.35^{* * *}$ & $-1.2 * * *$ & $-1.2^{* * *}$ & $-8.9^{* * *}$ & $-5.2^{* *}$ & $-2.3^{* *}$ \\
\hline CompF10 us CompF20 & ns & ns & $\mathrm{ns}$ & 3 & ns & ns \\
\hline CompF10+N us CompF20+N & ns & ns & ns & ns & ns & ns \\
\hline CompS10-20 us CompS10-20 +N & $-0.44 * * *$ & $-3.0 * * *$ & $-3.0 * * *$ & $-14.9 * * *$ & $-11.1 * * *$ & $-3.5^{* * *}$ \\
\hline CompS 10 us CompS 20 & ns & ns & ns & ns & ns & ns \\
\hline CompS $10+\mathrm{N}$ us CompS 20+N & ns & ns & ns & ns & ns & ns \\
\hline
\end{tabular}

CompF, municipal source separated organic fraction compost; CompS, olive pomace compost; CompF and CompS followed by 10 and 20 are the rates of compost, $+\mathrm{N}$ indicates the addition of mineral $\mathrm{N}$ fertilizer; $\mathrm{NPK}$, nitrogen-phosphorus-potassium; NFC, non-fertilised control; ns, not significant difference. The positive or negative values on the left of asterisks indicate the difference between the first (+) or the second (-) mean of the two contrasted groups; ${ }^{*}{ }^{* *},{ }^{* * *}$ indicate the significant levels of the contrasts, respectively $\mathrm{P}=0.05 ; \mathrm{P}=0.01 ; \mathrm{P}<0.001$.

Table 5. Fresh marketable yields and total dry matter biomass of onion cropped on autumn 2010-spring 2011 cycle, immediately after the second soil compost amendment.

\begin{tabular}{|c|c|c|c|c|c|c|}
\hline Treatments & $\begin{array}{c}\text { Leaves dry } \\
\text { matter } \\
\left(\mathrm{t} \mathrm{ha}^{-1}\right)\end{array}$ & $\begin{array}{c}\text { Bulbs dry } \\
\text { matter } \\
\left(\mathrm{t} \mathrm{ha}^{-1}\right)\end{array}$ & $\begin{array}{l}\text { Total dry } \\
\text { matter } \\
\left.(\mathrm{t} \mathrm{ha})^{-1}\right)\end{array}$ & $\begin{array}{c}\text { Marketable } \\
\text { yield } \\
\left(\mathrm{t} \mathrm{ha} \mathrm{a}^{-1}\right)\end{array}$ & $\begin{array}{l}\text { Mean bulb } \\
\text { diameter } \\
(\mathrm{cm})\end{array}$ & $\begin{array}{l}\text { Bulb mean } \\
\text { weight } \\
\text { (g) }\end{array}$ \\
\hline CompF10 & 0.41 & 2.1 & 2.5 & 20.2 & 7.0 & 89 \\
\hline CompF20 & 0.37 & 1.7 & 2.0 & 20.6 & 6.9 & 86 \\
\hline CompFl0+N & 0.50 & 2.1 & 2.6 & 27.0 & 7.6 & 115 \\
\hline CompF20+N & 0.60 & 2.5 & 3.1 & 30.7 & 8.0 & 133 \\
\hline CompS10 & 0.25 & 1.4 & 1.6 & 12.5 & 6.2 & 59 \\
\hline CompS20 & 0.17 & 0.9 & 1.1 & 7.5 & 5.5 & 41 \\
\hline CompS10+N & 0.43 & 1.8 & 2.2 & 22.3 & 7.3 & 95 \\
\hline CompS20+N & 0.33 & 1.7 & 2.0 & 17.5 & 7.0 & 86 \\
\hline NPK & 0.49 & 1.9 & 2.4 & 26.0 & 7.3 & 105 \\
\hline $\mathrm{NFC}$ & 0.34 & 1.5 & 1.8 & 16.9 & 6.6 & 77 \\
\hline \multicolumn{7}{|l|}{ Orthogonal contrasts } \\
\hline Compost $v s$ controls & ns & ns & ns & ns & ns & ns \\
\hline NPK us NFC & ns & ns & $0.58 *$ & $9.1^{* *}$ & $0.7^{*}$ & $27 * *$ \\
\hline CompF vs CompS & $0.17^{* * *}$ & $0.6^{* * *}$ & $0.8^{* * *}$ & $9.6^{* * *}$ & $0.8^{* * *}$ & $35^{* *}$ \\
\hline CompF10-20 us CompF10-20 +N & $-0.16^{* *}$ & $-0.38^{*}$ & $-0.5^{* * *}$ & $-8.4^{* * *}$ & $-0.8^{* *}$ & $-35^{* * *}$ \\
\hline CompF10 us CompF20 & ns & ns & ns & ns & ns & ns \\
\hline CompF10+N us CompF20+N & ns & ns & $-0.5^{*}$ & ns & ns & ns \\
\hline CompS10-20 us CompS10-20 +N & $-0.17 * *$ & $-0.6^{* * *}$ & $-0.7^{* * *}$ & $-9.8 * * *$ & $-1.3^{* * *}$ & $-40 * * *$ \\
\hline CompS 10 us CompS 20 & ns & $0.48^{*}$ & $0.5^{*}$ & ns & $0.7^{*}$ & ns \\
\hline CompS 10+N us CompS 20+N & ns & ns & ns & ns & ns & ns \\
\hline
\end{tabular}


treatments and that of the CompS ones: indeed, the higher NaUE values were in CompS plots where, conversely, the $\mathrm{N}$ uptake and REC were significantly lower than in the CompF group. In particular, regarding $\mathrm{N}$ apparent recovery (REC), its highest value was $56 \%$ in NPK while the amendment with CompS determined a negative recovery (on average 26\%) and only the amendment with CompF at the $10 \mathrm{tha}^{-1}$ dose, integrated or not by $\mathrm{N}$ fertiliser, showed a recovery of $12 \%$ from compost.

The following potato crop showed a nitrogen uptake in NFC significantly lower than NPK, unlike cauliflower (Table 8). This is attributable to the depletion of the more labile fraction of SOM, easily degradable by microorganisms. Plants grown in NPK treatment showed the highest $\mathrm{N}$ REC (39\%) and $\mathrm{N}$ removal by tubers $\left(2.7 \mathrm{~kg} \mathrm{mg}^{-1}\right)$ but they were less efficient in utilising absorbed nitrogen. Addition of $\mathrm{N}$ mineral to CompF and CompS significantly improved N uptake and N REC at both the rates supplied in comparison to the same rates without $\mathrm{N}$ fertiliser. The improvement in $\mathrm{N}$ availability influenced the NaUE on dry weight that was higher in the CompF and CompS plots not integrated by $\mathrm{N}$ fertiliser. The nitrogen recovery from CompS, averaging the 10 and 20 rates, was $16.5 \%$ when $\mathrm{N}$ fertiliser was added, while it decreased to $3.5 \%$ when $\mathrm{N}$ fertiliser was not added.

The onion crop followed the second compost distribution. As shown in Table 9, apparent nitrogen recovery in NPK (26\%) was significantly higher than compost treatments whose recovery was very low (max. $3 \%$ in CompF10+N and compF20+N). Total $\mathrm{N}$ uptake of the crop reached 60-63 $\mathrm{kg} \mathrm{ha}^{-1}$ in NPK and CompF20+N, respectively; it was higher in NPK versus NFC, in CompF versus CompS and, as already seen in the previous crops, in the compost fertilised crops when mineral $\mathrm{N}$ was added.

\section{Nitrogen budget}

Nitrogen surplus/deficit was assessed as the difference between total $\mathrm{N}$ input and total $\mathrm{N}$ output from each treatment after the 2-year crop sequence (Figure 1). N budget showed a surplus of 452-583 kg N ha $^{-1}$ in CompF20 and CompF20+N, respectively, while CompS20 and CompS20+N left a surplus of 267-398 kg N ha-1, respectively. The compost amendments at rate 10 gave a low surplus (CompF) or a slight deficit (CompS) while the addition of $\mathrm{N}$ fertiliser produced a surplus of

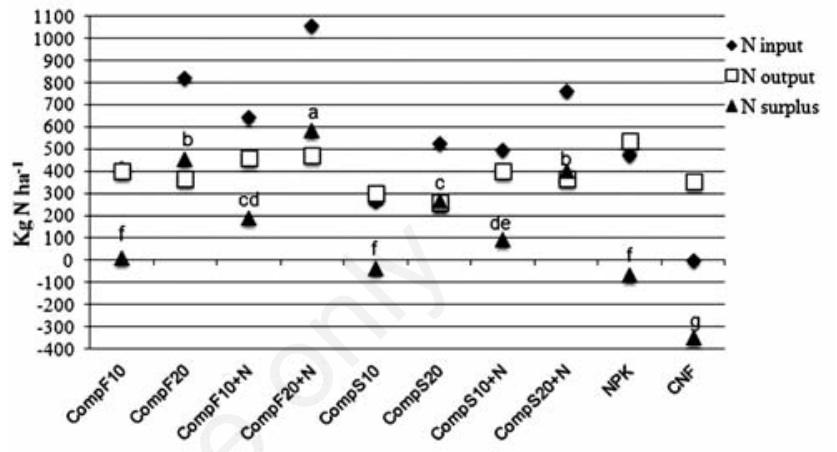

Figure 1. Cumulative nitrogen $(\mathrm{N})$ input and output in the whole crop sequence and $N$ surplus related to the different treatments. Different letters near the black triangle $\mathrm{N}$ surplus indicate significant differences among the means according to Tukey HSD test $(\mathbf{P}=\mathbf{0 . 0 5})$.

Table 6. Fresh marketable yields and total dry matter biomass of lettuce cropped on spring-summer 2011 cycle, after the onion crop.

\begin{tabular}{|c|c|c|c|c|}
\hline Treatments & $\begin{array}{l}\text { Total dry matter } \\
\qquad(\mathrm{t} \mathrm{ha-1)}\end{array}$ & $\begin{array}{l}\text { Marketable yield } \\
\qquad\left(\mathrm{t} \mathrm{ha^{-1 } )}\right.\end{array}$ & $\begin{array}{l}\text { Not marketable yield } \\
\qquad\left(\mathrm{t} \mathrm{ha}^{-1}\right)\end{array}$ & $\begin{array}{l}\text { Head mean weight } \\
\text { (g) }\end{array}$ \\
\hline CompF10 & 2.4 & 33.0 & 1.2 & 356 \\
\hline CompF20 & 2.2 & 33.3 & 1.1 & 358 \\
\hline CompF10+N & 2.6 & 43.6 & 0.7 & 461 \\
\hline CompF20+N & 2.6 & 44.6 & 0.2 & 466 \\
\hline CompS10 & 2.3 & 27.2 & 2.2 & 306 \\
\hline CompS20 & 2.2 & 23.4 & 3.3 & 279 \\
\hline CompS10+N & 2.5 & 41.7 & 0.0 & 434 \\
\hline CompS20+N & 2.6 & 37.2 & 1.2 & 399 \\
\hline NPK & 2.8 & 47.6 & 0.2 & 497 \\
\hline $\mathrm{NFC}$ & 2.1 & 19.2 & 3.2 & 232 \\
\hline \multicolumn{5}{|l|}{ Orthogonal contrasts } \\
\hline Compost $v s$ controls & ns & ns & ns & ns \\
\hline NPK us NFC & ns & $28.4^{* * *}$ & ns & $265^{* * *}$ \\
\hline CompF us CompS & ns & $6.2^{*}$ & ns & $55^{*}$ \\
\hline CompF10-20 us CompF10-20 +N & ns & $-10.9 * *$ & ns & $-106^{* *}$ \\
\hline CompF10us CompF20 & ns & ns & ns & ns \\
\hline CompF10+N us CompF20+N & ns & ns & ns & ns \\
\hline CompS10-20 vs CompS10-20 +N & ns & $-14.1^{* *}$ & ns & $-124^{* *}$ \\
\hline CompS 10 us CompS 20 & ns & ns & ns & ns \\
\hline CompS 10+N us CompS 20+N & ns & ns & ns & ns \\
\hline
\end{tabular}


Table 7. Total crop nitrogen $(\mathrm{N})$ uptake and $\mathrm{N}$ removal by marketable product of cauliflower, absorbed nitrogen use efficiency on dry and fresh weight, apparent recovery of $\mathrm{N}$.

\begin{tabular}{|c|c|c|c|c|c|}
\hline Treatment & $\begin{array}{l}\text { N uptake } \\
\left(\mathrm{kg} \mathrm{ha}^{-1}\right)\end{array}$ & $\begin{array}{c}\text { N removal by } \\
\text { head } \\
\left(\mathrm{kg} \mathrm{mg}^{-1}\right)\end{array}$ & $\begin{array}{c}\mathrm{N}_{\mathrm{a}} \mathrm{UE} \text { on } \\
\text { aboveground d.w. } \\
\left(\mathrm{kg} \mathrm{kg}^{-1}\right)\end{array}$ & $\begin{array}{l}\text { NaUE on marketable } \\
\text { yield f.w. } \\
\left(\mathrm{kg} \mathrm{kg}^{-1}\right)\end{array}$ & $\begin{array}{c}\text { Apparent recovery } \\
\text { of } \mathbf{N} \\
\%\end{array}$ \\
\hline CompF10 & 202 & 2.6 & 27 & 101 & 12 \\
\hline CompF20 & 174 & 2.7 & 29 & 85 & -0.7 \\
\hline CompF10+N & 209 & 2.8 & 27 & 86 & 12 \\
\hline CompF20+N & 198 & 3.1 & 28 & 81 & 4 \\
\hline CompS10 & 125 & 2.6 & 41 & 97 & -42 \\
\hline CompS20 & 103 & 2.8 & 42 & 104 & -30 \\
\hline CompS10+N & 150 & 3.1 & 38 & 106 & -15 \\
\hline CompS20+N & 125 & 2 & 44 & 107 & -17 \\
\hline NPK & 240 & 3.3 & 24 & 83 & 56 \\
\hline NFC & 178 & 3.5 & 33 & 85 & - \\
\hline \multicolumn{6}{|l|}{ Orthogonal contrasts } \\
\hline Compost $v s$ controls & $-48^{* * *}$ & $-0.7^{* * *}$ & $6 *$ & ns & $-65.2^{* * *}$ \\
\hline NPK us NFC & $62^{* * *}$ & ns & ns & ns & - \\
\hline CompF us CompS & $70^{*}$ & ns & $-13 * * *$ & ns & $32.8^{* * *}$ \\
\hline CompF10-20 us CompF10-20+N & ns & ns & ns & ns & ns \\
\hline CompF10 us CompF20 & ns & ns & ns & ns & ns \\
\hline CompF10+N us CompF20+N & ns & ns & ns & ns & ns \\
\hline CompS10-20 us CompS10-20+N & ns & ns & e & 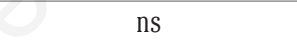 & $-20 * *$ \\
\hline CompS 10 us CompS 20 & ns & ns & $+\sqrt{2}$ & ns & ns \\
\hline CompS $10+\mathrm{N}$ vs CompS 20+N & ns & $1.1^{* * *}$ & ns & ns & ns \\
\hline
\end{tabular}

Table 8. Total crop nitrogen $(\mathrm{N})$ uptake and $\mathrm{N}$ removal by marketable product of potato, absorbed $\mathrm{N}$ use efficiency on dry and fresh weight, apparent recovery of $\mathrm{N}$.

\begin{tabular}{|c|c|c|c|c|c|}
\hline Treatment & $\begin{array}{l}\text { N uptake } \\
\left(\mathrm{kg} \mathrm{ha}^{-1}\right)\end{array}$ & $\begin{array}{l}\text { N removal } \\
\text { by tubers } \\
\left.\text { (kg } \mathrm{mg}^{-1}\right)\end{array}$ & $\begin{array}{c}\mathrm{N}_{\mathrm{a}} \mathrm{UE} \text { on } \\
\text { aboveground d.w. } \\
\left(\mathrm{kg} \mathrm{kg}^{-1}\right)\end{array}$ & $\begin{array}{l}\mathrm{N}_{\mathrm{a}} \mathrm{UE} \text { on } \\
\text { aboveground m.f.w. } \\
\left(\mathrm{kg} \mathrm{kg}^{-1}\right)\end{array}$ & $\begin{array}{c}\text { Apparent } \\
\text { recovery of } \mathrm{N} \\
\%\end{array}$ \\
\hline
\end{tabular}

\begin{tabular}{|c|c|c|c|c|c|}
\hline CompF10 & 72 & 1.8 & 94 & 390 & 2 \\
\hline CompF20 & 75 & 1.7 & 100 & 440 & 2 \\
\hline CompF10+N & 104 & 2.0 & 82 & 370 & 12 \\
\hline CompF20+N & 116 & 2.2 & 80 & 360 & 9 \\
\hline CompS10 & 66 & 1.9 & 93 & 390 & -2 \\
\hline CompS20 & 55 & 1.5 & 109 & 460 & -5 \\
\hline CompS10+N & 117 & 2.3 & 81 & 360 & 24 \\
\hline CompS20+N & 97 & 1.8 & 94 & 420 & 9 \\
\hline NPK & 132 & 2.7 & 62 & 290 & 39 \\
\hline NFC & 68 & 1.8 & 95 & 400 & - \\
\hline
\end{tabular}

\section{Orthogonal contrasts}

\begin{tabular}{|c|c|c|c|c|c|}
\hline Compost $v s$ controls & ns & ns & $13^{* *}$ & $50^{*}$ & $-32.5^{* * *}$ \\
\hline NPK us NFC & $64^{* * *}$ & $0.9^{* *}$ & $-33^{* *}$ & $-110^{* *}$ & - \\
\hline CompF us CompS & ns & ns & ns & ns & ns \\
\hline CompF10-20 us CompF10-20 +N & $-36.5^{* * *}$ & ns & $15^{*}$ & ns & $-9 *$ \\
\hline CompF10 us CompF20 & ns & ns & ns & ns & ns \\
\hline CompF10+N us CompF20+N & ns & ns & ns & ns & ns \\
\hline CompS10-20 us CompS10-20 +N & $-47 * * *$ & ns & $13^{*}$ & ns & $-20 * * *$ \\
\hline CompS10 us CompS20 & ns & ns & ns & ns & ns \\
\hline CompS10+N us CompS20+N & ns & ns & ns & ns & ns \\
\hline
\end{tabular}

$\mathrm{N}_{\mathrm{a}} \mathrm{UE}$, utilisation efficiency of absorbed nitrogen; d.w., dry weight; m.f.w., marketable fresh weight; CompF, municipal source separated organic fraction compost; N, nitrogen; CompS, olive pomace compost; CompF and CompS followed by 10 and 20 are the rates of compost, $+\mathrm{N}$ indicates the addition of mineral $\mathrm{N}$ fertilizer; NPK, nitrogen-phosphorus-potassium; NFC, non-fertilised control; ns, not significant difference.

The positive or negative values on the left of asterisks indicate the difference between the first $(+)$ or the second (-) mean of the two contrasted groups; ${ }^{*},{ }^{* *},{ }^{* * *}$ indicate the significant levels of the contrasts, respectively $\mathrm{P}=0.05 ; \mathrm{P}=0.01 ; \mathrm{P}<0.001$. 
187 in CompF10 and $96 \mathrm{~kg} \mathrm{ha}^{-1}$ in CompS. This second group of treatments differed significantly from the first group described above. NFC showed a deficit of $351 \mathrm{~kg} \mathrm{~N} \mathrm{ha}^{-1}$ while NPK showed a deficit of $65 \mathrm{~kg}$ $\mathrm{N} \mathrm{ha}^{-1}$. The result nearest to zero was in CompF10 but the CompF10+N treatment, with a surplus of $187 \mathrm{~kg} \mathrm{~N} \mathrm{ha}^{-1}$, met the needs for high crop productivity. On the other hand, CompS10 gave a deficit linked to the low amount of $\mathrm{N}$ distributed (Table 2); the addition of $\mathrm{N}$ fertiliser to CompS10 helped to achieve more acceptable results (yields and $\mathrm{N}$ balance) among all the CompS treatments. Both the composts applied at the rate 20 gave high surplus of $\mathrm{N}$ in soil.

\section{Soil organic matter balance}

Table 10 shows the final SOC content, the SOC change occurred between the start of amendments and the end of the second year, and the conversion efficiency of carbon in compost to carbon in soil. The biennial compost carbon input clearly shows the bigger amount supplied by CompS compared to CompF with the equal rates calculated according to dry matter. Final SOC content ranged from $48 \mathrm{t} \mathrm{ha}^{-1}$ in NFC to $55.4 \mathrm{t} \mathrm{ha}^{-1}$ in CompF20 with or without $\mathrm{N}$ addition. The orthogonal contrasts showed either for SOC content or for SOC change after two years, a highly significant difference of $5 \mathrm{t} \mathrm{ha}^{-1}$ between the compost treatments and the Controls. CompS determined an average improvement of $1.1 \mathrm{t} \mathrm{ha}^{-1}$ compared to CompF. The amendment with CompF at rate 20 caused a higher SOC content than rate 10. Instead, CompS rates determined, in general, higher final SOC content. Conversion efficiency, taking into account the SOC change in relation to the carbon input, showed that CompS was more efficient than CompF with a mean conversion coefficient of $22 \%$ while CompF at rate 10 had a negative conversion efficiency, and at rate 20 had the highest conversion efficiency of $33 \%$.

\section{Discussion}

The high C:N ratio and the lowest total $\mathrm{N}$ content of CompS (see Materials and methods section, Table 2), probably increased the competition for nitrogen between soil microorganisms and plant roots, reducing crop growth (Amlinger et al., 2007). The findings of Garcia-Ruiz et al. (2009) in an olive oil orchard support our hypothesis. They found that, in the short term (3-12 months), olive pomace compost decomposition immobilised $\mathrm{N}$ and reduced the $\mathrm{N}$ lost as nitrate, while in the long term (15 years of repeated amendments), either soil organic matter and total $\mathrm{N}$ or the potential nitrification rate and the $\mathrm{N}$ easily mineralised pool were increased. In our research, consistent with these findings, the first crops (cauliflower and onion) more than the second crops (potato and lettuce), following the annual distribution of CompS to the soil, showed low $\mathrm{N}$ uptake, negative $\mathrm{N}$ recovery, and yields as low as in the non-fertilised control. These negative results worsened as the amount of compost supplied increased.

If we consider the apparent recovery fraction of nitrogen without addition of $\mathrm{N}$ fertiliser, values recorded with CompF ranged from $2 \%$ to

Table 9. Total crop nitrogen $(\mathrm{N})$ uptake and $\mathrm{N}$ removal by marketable product of onion, absorbed $\mathrm{N}$ use efficiency on dry and fresh weight, apparent recovery of $\mathrm{N}$.

\begin{tabular}{|c|c|c|c|c|c|}
\hline Treatment & $\begin{array}{l}\text { N uptake } \\
\left(\mathrm{kg} \mathrm{ha}^{-1}\right)\end{array}$ & $\begin{array}{l}\text { N removal } \\
\text { by leaves+bulbs } \\
\left(\mathrm{kg} \mathrm{mg}^{-1}\right)\end{array}$ & $\begin{array}{l}\mathrm{N}_{\mathrm{a}} \mathrm{UE} \text { on } \\
\text { aboveground d.w. } \\
\left(\mathrm{kg} \mathrm{kg}^{-1}\right)\end{array}$ & $\begin{array}{l}\mathrm{N}_{\mathrm{a}} \mathrm{UE} \text { on } \\
\text { aboveground m.f.w. } \\
\left(\mathrm{kg} \mathrm{kg}^{-1}\right)\end{array}$ & $\begin{array}{c}\text { Apparent } \\
\text { recovery of } \mathbf{N} \\
\%\end{array}$ \\
\hline CompF10 & 39 & 1.9 & 67 & 520 & 2.7 \\
\hline CompF20 & 37 & 1.8 & 58 & 570 & 0.7 \\
\hline CompF10+N & 51 & 1.9 & 50 & 530 & 3 \\
\hline CompF20+N & 63 & 2.1 & 50 & 490 & 3 \\
\hline CompS10 & 23 & 1.8 & 73 & 550 & -2.3 \\
\hline CompS20 & 19 & 2.5 & 59 & 410 & -2 \\
\hline CompS10+N & 42 & 1.8 & 54 & 540 & 2.3 \\
\hline CompS20+N & 43 & 2.4 & 48 & 410 & 2 \\
\hline NPK & 60 & 2.3 & 42 & 440 & 26 \\
\hline NFC & 29 & 1.8 & 65 & 580 & - \\
\hline \multicolumn{6}{|l|}{ Orthogonal contrasts } \\
\hline Compost vs controls & ns & ns & ns & $-140^{*}$ & $-24 * * *$ \\
\hline NPK us NFC & $31^{* * *}$ & $0.5^{*}$ & $-23^{* *}$ & ns & - \\
\hline CompF vs CompS & $15^{* * *}$ & ns & ns & $\mathrm{ns}$ & $2.5^{*}$ \\
\hline CompF10-20 us CompF10-20 +N & $-19 * * *$ & ns & $12^{*}$ & ns & ns \\
\hline CompF10 vs CompF20 & ns & ns & ns & ns & ns \\
\hline CompF10+N us CompF20+N & ns & ns & ns & ns & $-4^{* *}$ \\
\hline CompS10-20 usCompS10-20 +N & $-21 * * *$ & ns & $14^{*}$ & ns & ns \\
\hline CompS10 us CompS20 & ns & $-0.7^{* *}$ & ns & $130^{*}$ & ns \\
\hline CompS10+N vs CompS20+N & ns & $-0.6^{*}$ & ns & $120^{*}$ & ns \\
\hline
\end{tabular}

$\mathrm{N}_{\mathrm{a}} \mathrm{UE}$, utilisation efficiency of absorbed nitrogen; d.w., dry weight; $\mathrm{m}$.f.w., marketable fresh weight; CompF, municipal source separated organic fraction compost; $\mathrm{N}$, nitrogen; CompS, olive pomace compost; CompF and CompS followed by 10 and 20 are the rates of compost, $+\mathrm{N}$ indicates the addition of mineral $\mathrm{N}$ fertilizer; NPK, nitrogen-phosphorus-potassium; NFC, non-fertilised control; ns, not significant difference. The positive or negative values on the left of asterisks indicate the difference between the first $(+)$ or the second $(-)$ mean of the two contrasted groups; ${ }^{*},{ }^{* *},{ }^{* * *}$ indicate the significant levels of the contrasts, respectively $\mathrm{P}=0.05 ; \mathrm{P}=0.01 ; \mathrm{P}<0.001$. 
$12 \%$ and from -2 to $-42 \%$ with CompS. CompS, within a year of its distribution, released mineral nitrogen very slowly and did not satisfy crop needs. As reported from the European Compost Network (2010), the results collected from the long-term trial series carried out in Germany showed that, in short-term trials (1-3 years) an average 3-5\% of the $\mathrm{N}$ supplied with compost per annum can be accounted for by the fertilising calculation. Under favourable conditions, the $\mathrm{N}$ utilisation rate can increase up to $10 \%$. On the contrary, in the medium term (4-12 years), the $\mathrm{N}$ recovery can rise to an average $5-12 \%$; under favourable conditions it can increase up to $20 \%$. In a cumulative time of application, there is an increasing $\mathrm{N}$-mineralisation from the organic compost substance as a consequence of the humus enrichment and the growing microbiological activation (Garcia-Ruiz et al., 2009). On the basis of these findings, and in agreement with Mamo et al. (1999), Alfano et al. (2009b), Altieri et al. (2010), and the ECN (2010), we emphasise the positive effects on yields and $\mathrm{N}$ nutrition by the addition of a reduced rate of $\mathrm{N}$ fertiliser, particularly in the first period of compost amendment. It has to be specified that the halved rate of $\mathrm{N}$ fertiliser added to olive pomace compost was sufficient to overcome the competition between soil microorganisms and roots for $\mathrm{N}$ only on the second crop in the annual sequence.

With regard to the significance of the $\mathrm{N}_{\mathrm{a}} \mathrm{UE}$ index, we observed that the higher the $\mathrm{N}_{\mathrm{a}} \mathrm{UE}$ on aboveground biomass dry weight, the lower the $\mathrm{N}$ uptake and the apparent recovery fraction of N. So, a high $\mathrm{N}_{\mathrm{a}} \mathrm{UE}$ index seems to indicate problems in the $\mathrm{N}$ nutrition of crops, as also reported by Benincasa et al. (2011).

The cumulative $\mathrm{N}$ budget showed greater excess in the CompF20+N and CompF20 treatments, followed by CompS20+N and compS20. In the NFC treatment, a depletion of $350 \mathrm{~kg} \mathrm{ha}^{-1}$ was observed over the two years consistent with an increasing loss in productivity. The other soil amendments with rate 10 showed a final budget ranging from $-34 \mathrm{~kg}$ $\mathrm{ha}^{-1}$ of CompS10 to $187 \mathrm{~kg} \mathrm{ha}^{-1}$ of CompF10+N while in MIN the amount of $\mathrm{N}$ supplied was slightly below crop needs. Reider et al. (2000), in a short rotation (3 years) of corn, pepper and small grains, found treatments with different composts gave, in general, a surplus (485-865 $\mathrm{kg} \mathrm{ha}^{-1}$ ) in the $\mathrm{N}$ budget. Nevertheless, it should be noted that over $80 \%$ of $\mathrm{N}$ supplied with compost is in an organic form that is not immediately available for plants. Therefore, it does not seem appropriate to hypothesise that the $\mathrm{N}$ surplus in compost-amended plots is will directly increase $\mathrm{N}$ loss through leaching, erosion, runoff, or volatilisation (Fagnano et al., 2011).

The fate of $\mathrm{N}$ in rice straw or cattle manure composts was evaluated by Nishida (2009) applying the ${ }^{15} \mathrm{~N}$-labeling technique. The ${ }^{15} \mathrm{~N}$ labelled compost was applied in the first of five rice seasons, and the $\mathrm{N}$ recovery from compost was then determined. The percentages of compost ${ }^{15} \mathrm{~N}$ recovery were $3-6 \%$ and $2-3 \%$ per year for rice straw compost and cattle manure compost, respectively. The author concluded that compost $\mathrm{N}$ was steadily taken up over many years, the contribution of compost $\mathrm{N}$ cumulatively increasing with each successive application.

The slightly higher SOC content caused by CompS compared to CompF seemed to suggest a low decomposition rate of the former in agreement with Garcia-Ruiz et al. (2012). Nevertheless, due to the short period of amendment, the results obtained should be considered with caution. The findings of Garcia-Ruiz et al. (2012) clearly showed

Table 10. Soil organic carbon content and its variation after the 2-year period of trial; conversion efficiency of carbon (C) supplied by compost to soil C.

\begin{tabular}{|c|c|c|c|c|}
\hline Treatments & $\begin{array}{l}\text { st carbon input } \\
\left(\mathrm{t} \mathrm{ha^{-1 } )}\right.\end{array}$ & $\begin{array}{l}\text { SOC in } 2011 \\
(\mathrm{t} \mathrm{ha-1)}\end{array}$ & $\begin{array}{c}\text { SOC change } \\
\text { in 2011-2009 period } \\
\left(\mathrm{t} \mathrm{ha}^{-1}\right)\end{array}$ & $\begin{array}{c}\text { Conversion efficiency } \\
\text { of compost } \mathrm{C}^{\#} \\
(\%)\end{array}$ \\
\hline CompF10 & 5.7 & 51.0 & -0.7 & -12 \\
\hline CompF20 & 11.4 & 55.4 & 3.7 & 33 \\
\hline CompF10+N & 5.7 & 51.0 & -0.9 & -16 \\
\hline CompF20+N & 11.4 & 55.4 & 3.7 & 33 \\
\hline CompS10 & 7.8 & 53.6 & 1.9 & 24 \\
\hline CompS20 & 15.6 & 55.0 & 3.5 & 23 \\
\hline CompS10+N & 7.8 & 53.5 & 1.9 & 24 \\
\hline CompS20+N & 15.6 & 54.6 & 2.9 & 19 \\
\hline NPK & - & 49.6 & -2.1 & - \\
\hline NFC & - & 48.0 & -3.7 & - \\
\hline \multicolumn{5}{|l|}{ Orthogonal contrasts } \\
\hline Compost $v s$ controls & - & $5^{* * *}$ & $4.9 * * *$ & - \\
\hline NPK us NFC & - & ns & ns & - \\
\hline CompF us CompS & - & $-1.1^{*}$ & $-1.1^{*}$ & $-12^{*}$ \\
\hline CompF10 +N/no N us CompF20 +N/no N & - & $-4.5^{* * *}$ & $-4.5^{* * *}$ & $-47^{* * *}$ \\
\hline CompF10+N us CompF10 no N & - & ns & ns & ns \\
\hline CompF20+N us CompF20 no N & - & ns & ns & ns \\
\hline CompS10 +N/no N us CompS20 +N/no N & - & ns & ns & ns \\
\hline CompS10+N us CompS10 no N & - & ns & ns & ns \\
\hline CompS20+N us CompS20 no N & - & ns & ns & ns \\
\hline
\end{tabular}


the positive effects of olive pomace compost on the increase in SOC content in olive groves amended for 4 or 9 or 16 years. In our agro-system, soil tillage frequency was high (Table 1) and SOC mineralisation was favoured. The amount of CompF able to exceed the soil mineralisation rate was $20 \mathrm{t}$ d.m. ha ${ }^{-1}$ (corresponding to $11.4 \mathrm{t} \mathrm{C} \mathrm{ha}^{-1}$ ) while rate 10 was completely mineralised giving a negative SOC change over the 2-year period. Rate 20 of CompF was linked not only to the highest conversion efficiency of $\mathrm{C}$ compost, but also to the highest soil $\mathrm{N}$ surplus among the compared treatments. On the contrary, the rate of CompS to be used appeared to be $10 \mathrm{t} \mathrm{d.m.} \mathrm{ha-1} \mathrm{(corresponding} \mathrm{to} 7.8 \mathrm{t}$ $\mathrm{C} \mathrm{ha}^{-1}$ ). This rate, when integrated by $\mathrm{N}$ fertiliser, well coupled the $\mathrm{C}$ balance to the crop yields and produced acceptable values of the NUE indexes and $\mathrm{N}$ surplus. On the contrary, the rate 20 of CompS gave a SOC change equal to that obtained with the same rate of CompF but the immobilisation of nitrogen in soil meant poorer utilisation efficiency.

\section{Conclusions}

In Italy, biowaste compost is the most abundant type of compost due to the increase in source-separated collection of urban waste products. Nevertheless, availability of olive pomace compost could increase, particularly where olive orchards are widespread. Therefore, we need to understand how to use organic soil improvers with different chemicalphysical characteristics and know what results to expect. Our findings show the tested rates of olive pomace compost reduced the $\mathrm{N}$ availability for crops while the addition of $\mathrm{N}$ mineral fertilisers helps to counteract these problems. However, despite the slow degradability of the olive pomace compost, there was a slight increase in total soil organic carbon, probably due to frequent soil tillage. The biowaste compost, while slowing down $\mathrm{N}$ release in the first year of application, went on to produce higher $\mathrm{N}$ mineralisation than the olive pomace compost. However, when the total $\mathrm{N}$ content of a compost is around $2 \%$, we have to be careful when we establish the amount to be applied so that we can comply with the Action Programme for the areas at risk of nitrate pollution. In order to achieve the target of correctly planning the fertilisation of crops amended by compost, further research is needed to define the $\mathrm{N}$ mineralisation rates of compost over time. Achievement of this objective goes hand in hand with the identification of the amount of $\mathrm{C}$ to be made with the compost in order to obtain an increase in the soil organic $\mathrm{C}$.

\section{References}

Alburquerque JA, Gonzalvez J, Garcia D, Cegarra J, 2006a. Composting of a solid olive-mill product ("alperujo") and the potential of the resulting compost for cultivating pepper under commercial conditions. Waste Manage. 26:620-6.

Alburquerque JA, Gonzalvez J, Garcia D, Cegarra J, 2006b. Measuring detoxification and maturity in compost made from "alperujo", the solid by-product of extracting olive oil by the two-phase centrifugation system. Chemosphere 64:470-7.

Alfano G, Belli C, Lustrato G, Ranalli G, 2008. Pile composting of twophase centrifuged olive husk residues: technical solutions and quality of cured compost. Bioresour. Technol. 99:4694-701.

Alfano G, Lustrato G, Lima G, Ranalli G, 2009a. Present and future perspectives of olive residues composting in the Mediterranean basin. Dynamic Soil Dynamic Plant 3:39-56.

Alfano G, Lustrato G, Lima G, Vitullo D, Delfine S, Tognetti R, Ranalli G, 2009b. Physico-chemical, microbiological, agronomical and phy- topathological aspects in the re cycling of olive waste composted residues. Dynamic Soil Dynamic Plant 3:64-72.

Altieri R, Esposito A, 2010. Evaluation of the fertilizing effect of olive mill waste compost in short-term crops. Int. Biodeter. Biodeg. 64:124-8.

Altieri R, Esposito A, 2012. Valutazione di un nuovo metodo di compostaggio on-farm dei reflui dei frantoi oleari. Acta Italus Hortus 5:347.

Amlinger F, Peyr S, Geszti J, Dreher P, Nortcliff S, 2007. Beneficial effects of compost application on fertility and productivity of soils Literature study. Federal Ministry of Austria for Agriculture and Forestry, Environment and Water Management, Wien, Austria, pp $1-235$.

Assessorato Agricoltura Regione Campania, 2003. Guida alla concimazione. Regione Campania, Napoli, Italy. Available from: http//www.agricoltura.regione.campania.it/concimazione/guida.htm

Assessorato Agricoltura Regione Campania, 2008. Programma di Azione - per le zone vulnerabili all'inquinamento dei nitrati di origine agricola. Regione Campania, Napoli, Italy, pp 1-45.

Baeta-Hall L, Ceu Saagua M, Bartolomeu ML, Anselmo AM, Rosa MF, 2005. Bio-degradation of olive oil husks in composting aerated piles. Bioresource Technol. 96: 69-78.

Benincasa P, Guiducci M, Tei F, 2011. The nitrogen use efficiency: meaning and sources of variation. Hort. Technol. 21:266-73.

Canet R, Pomares F, Cabot B, Chaves C, Ferrer E, Ribò M, Albiach MR, 2008. Composting olive mill pomace and other residues from rural southeastern Spain. Waste Manage. 28:2585-92.

Diacono M, Vitti C, Debiase G, Verrastro V, Ceglie FG, Tittarelli F, 2009. Potential use of olive pomace compost as amendment on a cickpeaemmer rotation in organic farming. pp 61-66 in Proc. 18th Symp. Int. Scientific Centre of Fertilizers, Roma, Italy.

European Compost Network, 2010. Sustainable compost application in agriculture - English Version of the summary of German report. ECN-INFO, Bochum, Germany, p 36.

Fagnano M, Adamo P, Zampetti M, Fiorentino N, 2011. Environmental and agronomic impact of fertilization with composted organic fraction from municipal solid waste: a case study in the region of Naples, Italy. Agr. Ecosyst. Environ. 141:100-7.

Garcia-Ruiz R, Ochoa MV, Gomez B, Alvarez de la Puente JM, 2009. Does the composted olive mill pomace increase the sustainable $\mathrm{N}$ use of olive oil cropping? In C. Grignani, M. Acutis, L. Zavattaro, L. Bechini, C. Bertora, P. Marino Gallina, D. Sacco (eds.) Proc. 16th Nitrogen Workshop on Connecting different scales of nitrogen use in agriculture, Torino, Italy.

Garcia-Ruiz R, Ochoa MV, Hinojosa MB, Gomez-Munoz B, 2012. Improved soil quality after 16 years of olive mill pomace application in olive oil groves. Agron. Sustain. Dev. 32:803-10.

Gent MPN, 2002. Growth and composition of salad greens as affected by organic compared to nitrate fertilizer and by environment in high tunnels. J. Plant Nutr. 25:991-8.

Hachicha S, Chtourou M, Medhioub K, Ammar E, 2006. Compost of poultry manure and olive mill wastes as an alternative fertilizer. Agron. Sustain. Dev. 26:135-42.

Lopez-Bellido L, Lopez-Bellido RJ, Redondo R, 2005. Nitrogen efficiency in wheat under rainfed Mediterranean conditions as affected by split nitrogen application. Field Crop Res. 94:86-97.

Mamo M, Rosen C J, Halbach TR, 1999. Nitrogen availability and leaching from soil amended with municipal solid waste compost. J. Environ. Qual. 28:1074-82.

Marsic KN, Osvald J, 2002. Effects of different nitrogen levels on lettuce growth and nitrate accumulation in iceberg lettuce (Lactuca sativa var. capitata L.). Gartenbauwissenschaft. 67:128-34.

Montemurro F, Convertini G, Ferri D, 2004. Mill wastewater and olive 
pomace compost as amendments for rye-grass. Agronomie 24:4816.

Morra L, Bilotto M, Ingenito MR, Pinto V, Valentini F, 2012. Risultati di un biennio di prove di compostaggio di sanse olearie e qualità dei compost ottenuti. Acta Italus Hortus 5:38-43.

Nishida M, 2009. Nitrogen use efficiency of compost in a paddy field: evaluation using $15 \mathrm{~N}$-labeled compost in a successive application system. In: C. Grignani, M. Acutis, L. Zavattaro, L. Bechini, C. Bertora, P. Marino Gallina, D. Sacco (eds.) Proc. 16th Nitrogen Workshop on Connecting different scales of nitrogen use in agriculture, Torino, Italy.

Pardini G, Gispert M, Jordana R, Velayos J, 2008. Experimental use of composted grape seed and olive mill residues for amelioration of fertility and structural stability of soils. Compost Sci. Util. 16:61-8. Reider CR, Herdman WR, Drinkwater LE, Janke R, 2000. Yields and nutrient budgets under composts, raw dairy manure and mineral fertilizer. Compost Sci. Util. 8:328-39.

Rigane H, Medhioub K, 2011. Co-composting of olive mill wastewater with manure and agro-industrial wastes. Compost Sci. Util. 19:129-34.

Roig A, Cayuela ML, Sanchez-Monedero MA, 2006. An overview on olive mill wastes and their valorisation methods. Waste Manage. 26:960-9.

Tei F, Benincasa P, Guiducci M, 2003. Critical nitrogen concentration in lettuce. Acta Hort. 627:187-94.

Vallini G, Pera A, Morelli R, 2001. Il compostaggio delle acque di vegetazione dei frantoi oleari. L'Informatore Agrario 50:22-6. 